\title{
Improvement of the mechanism of innovative development of small and medium-sized enterprises
}

\section{Ihor Kobushko}

Doctor of Economic Sciences, Professor, Department of Finance and Credit, Sumy State University, Ukraine

\section{Octavian Jula}

Ph.D. in Economic Sciences, Associate Professor, Faculty of Economics and Business Administration, Babes Bolyai University, Romania

\section{Maryna Kolesnyk}

Ph.D. Student, Sumy State University, Ukraine

(C) The Authors, 2017. This article is published with open access at ARMG Publishing.

\begin{abstract}
The article studies the innovative activity of small and medium-sized enterprises. The main obstacles to the innovative development of small and medium-sized enterprises were determined. The scenarios of correspondence between potential of innovation and potential of the enterprise, as well as the methodology of determining the innovative potential of small and medium-sized enterprises are given. The paper describes the algorithm and financial and legal mechanism of the innovative development of small and medium-sized enterprises, which includes a set of goals, ideas, tasks, tools, principles and innovative development factors. Depending on the combination of the values of the factors of five-component indicator, six levels of innovative development of small and medium-sized enterprises are established in research.
\end{abstract}

Keywords: innovations, innovative potential, innovative development, small and medium-sized enterprises, innovations assessment.

JEL Classification: O30, O31, O32.

\section{Introduction}

Innovation is a key aspect of determining the level of country development as a whole, as well as each separate enterprise. Under conditions of modern global economy there is a need for innovative development not only among large companies but also enterprises of small and medium-sized business. However, small and medium-sized enterprises tend to be less innovative than large companies. Innovative characteristics increase with the size of the company.

Special innovative efforts on the promotion of the innovations, connected with the lack of resources, are needed for the development of small and medium-sized enterprises (SMEs). Small and medium businesses have the equipment of lower quality in comparison with large enterprises. On the other hand, the advantages of SMEs include the targeted use of existing resources, faster and less bureaucratic decision-making processes, they are more close to customers, they are more flexible than larger organizations because their internal structures are less integrated. Thus, these factors help SMEs to adapt to new market conditions more quickly.

The research objective is to determine the innovative potential and justify the concept of financial and legal mechanism of the innovative development of small and medium-sized enterprises that is aimed at the enhancing competition in today's market conditions.

\section{Literature review}

The innovative development of enterprises was studied by such foreign and domestic researchers as: O. Amosha, Yu. Bazhal, P. Zavlin, M. Lapin, S. Illyashenko, B. Stadnyk, R. Ernst-Siebert, S. Minder, S. Walther, U. Becker, P. Ulrich, J. Schumpeter and such researchers as I. Kondrashkina, A. Gusarov, P. Kuzmishyn, D. Isachenko study the innovative development of small and medium-sized enterprises in Ukraine and abroad. 
Questions and problems of development of the individual tools and mechanisms of small and medium enterprises in developing countries, are considered in the papers of N. Arakelyan, A. Akhmetov, A. Gilmutdinova, M. Gurov, S. Demin, E. Egorova, M. Ivanova, A. Korchagin, A. Lipkes, I. Polonsky, S. Ulyanov, V. Shvedova.

However, it should be noted the absence of use of the experience of small and medium enterprises in the developed countries for Ukrainian enterprises to increase their competitiveness.

\section{Methods used in the research}

For the preparation of the articles a major role played by the works of national and foreign scientists on the problems of innovative development of small and medium enterprises, intellectual property management, monographs, periodicals materials on the studied problems, publication on the Internet.

Information and statistical database for the study has a data of national and international organizations. The methods of macroeconomic analysis, deduction and induction, methods of statistical analyze system, logical and comparative analysis, economic and mathematical methods, and method of experts' evaluation were as methodological bases.

\section{Description of findings}

Despite the large number of research on the development of small and medium business, many aspects of this problem require in-depth system approach. The concept of the formation of an effective financial and legal mechanism, which is based on systemic changes to ensure the innovative development of small and mediumsized enterprises, is not developed enough.

At the moment, there is a need to justify the methods of coordination of public administration and internal capabilities of SMEs, which are aimed at sustainable and growing of end result.

The government influence and support for the development of SMEs become of great importance. Thus, there is a need for creating of an effective mechanism on providing the favorable conditions in economic, political and social fields of SMEs activity. State policy, aimed at the development of SMEs, is characterized by two main directions: firstly, it is the decrease of monopoly by supporting small and medium-sized businesses; secondly, it is an indirect influence of the government on the development of small and medium-sized businesses at the domestic level and individual regions by means of supporting the scientific and research and development activities, the introduction of new forms of cooperation, the development of effective legislative framework, etc. Effective government support of SMEs is the most important factor of improving the competitiveness and effective cooperation with foreign enterprises.

The factors constraining the development of innovative activity of small and medium-sized enterprises are as follows:

1. technological (absence of own advanced technologies of production, lack of material and technical base, absence of experimental facilities);

2. economic (absence and lack of financing of innovative projects, high economic risks, absence of financing in small and medium-sized businesses, absence of information about new markets);

3. professional training of personnel (absence, lack of correspondence or low level of basic training, absence of conditions for participation in creative scientific activity, imperfection of motivation system of professional development, absence of training centers);

4. legal (instability of domestic legislation, limitations by tax, amortization, patent and licensing legislation, the vulnerability of the intellectual research results);

5. organizational and managerial (imperfection of organizational structures, underdeveloped innovative infrastructure, short-term period orientation, the lack of coordination of participants of the innovation process) [1].

The determination of the correspondence between the potential of innovation and potential of the enterprise is one of the key problems which small and medium-sized enterprises face to. The following is conducted for this:

$>$ measurement of innovative potential of enterprise;

$>$ measurement of innovative potential of innovation;

$>$ comparison of the two types of potentials and development of the recommendations for the rational scenario of innovation implementation. 
Depending on the results of comparison of the enterprise innovative potential and potential of innovations, one of several fundamental scenarios can be chosen: an independent implementation of innovations on the basis of financing scheme development, integration with large company, choosing rational time to sell the project.

It is proposed to carry out the comparison of two kinds of potentials on the basis of life-cycle concept. From this point of view, three typical scenarios can be pointed out, each one is characterized by its approach to the assessment of the innovative potential:

1. Innovative project coincides with the innovating enterprise. Life cycles of project and enterprise are identical.

2. Existing innovative enterprise implements new innovative project as its component.

3. Existing innovative enterprise implements new innovative project making it separate legal entity. This scenario is a special case of 1 or 2 variants, depending on the specific situation, that will be discussed below.

\section{Scenario 1. Innovative project coincides with the innovating enterprise}

The overwhelming majority of innovative small enterprises are created in order to promote a new product in the market. In this case, to implement a specific innovative project, the enterprise is created "from scratch". The stages of the life cycle of enterprise and project coincide.

In this case, the assessment of innovative potential is reduced to the assessment of economic efficiency of the innovative project and includes the following blocks:

1. Assessment of investment economic efficiency of the project.

2. Assessment of risks system and uncertainties of the project.

\section{Scenario 2. Existing innovative enterprise implements new innovative project as its component}

Small innovative enterprise starts to seek new market sectors as sales grow and fill the primary market niche. The current phase of the operation of enterprise is the stage of expansion, development and growth. At this stage, the company makes a decision on the implementation of one or another innovative project.

In these cases, while carrying out the assessment of the innovative potential, the project should not be viewed apart from the enterprise, it is important to take into account the synergistic effect of the business. Two types of projects can be distinguished from this point of view: (1) innovation fits very well into the business of the company; (2) the project provides the expansion of the field of company activity.

Depending on the time of the carried assessment the project can be at any stage of the life cycle:

1. The innovative project is in the starting at stage of life cycle.

2. The innovative project is at the later stages of the life cycle, and almost is not separated from the enterprise.

In fact, this is one of the business directions of the company operating.

In the first case, the assessment of project efficiency and innovative activity at particular enterprise as a whole is carried out. The innovative potential of the enterprise consists of the potential of innovative project as such; preconditions which the innovating enterprise has (business potential of the company).

Innovative project that is effective for one enterprise may turn out to be not effective for another one due to objective and subjective reasons.

In the second case the integral assessment of the business potential of the company is conducted. This assessment includes the following blocks:

1. The assessment of the business potential of the company.

2. The assessment of the business value by income method.

3. The assessment of system of risks and uncertainties of the company.

Scenario 3. The enterprise, acting in the growth stage, is the initiator of project

New legal entity (spinning company) is created for its implementation. The stage of enterprise lifecycle is further.

Spinning company ("Spin-off") is a company that is firstly created at the enterprise (at scientific and research institute, university) as a structural subdivision but then decided to become a separate company. In this case an independent company is created, not the "subsidiary" one. 
In general, the assessment methodology corresponds to scenario 1, but the potential of innovating enterprise of the project, as well as the feasibility of creating a new spinning company, are taken into account. The assessment corresponds to scenario 2 in case the separation of spinning company into an independent business was caused by the request of the "parent company" with purpose of its further sale.

Determination of innovative potential consists of 4 blocks:

1. Assessment of project efficiency provides the value determination of the investments needed to achieve the result; determining the range of possible financing schemes; the choice of rational scheme of financing; assessment of the financial consequences of the investment; definition of the level of standard of investment efficiency, the identification of the standard return period, etc.

2. Assessment of business potential of the company (project) includes:

$>$ Scientific potential (assessment of the scientific potential of the enterprise involves the analysis of the company's ability to conduct research and development, as well as opportunities for the implementation of scientific research accumulated by enterprise in the market).

$>$ Market potential (analysis of market potential allows to understand whether the enterprise (project, product) has a real chance of success, whether the product (project) corresponds to specific needs of market; to assess the mechanisms that transmit new technological opportunities into the market, the knowledge of market, where the enterprise is going to implement its idea and the ability to organize the market interactions and apply the marketing tools, are extremely important factors while technology commercialization).

$>$ Production potential (assessment of enterprise production potential implies the analysis of the available opportunities (rules, methods and techniques) of the embodiment of an idea (product manufacturing), or an assessment of the technical feasibility of bringing the idea to the stage of the product readiness for use or sale).

3. Assessment of risks and uncertainties provides carrying out the calculations of change of parameters and indicators of project efficiency (change of enterprise value assessment) due to the risks and possible managerial decisions on their reduction or accounting for uncertainties and includes the following stages: setting the assessment task; selection of input data combinations for assessment; search and preliminary analysis of possible solutions and corrective measures to minimize the damage from risks; calculation of project parameters and evaluation of the effectiveness at various variants of decisions and measures at all selected combinations of input data; analysis and choice of rational variants of the project implementation; a final decision making.

4. Estimation of innovative business value is traditionally conducting by using the following three approaches: profitable, market-based and assets-based. The use of a particular approach depends on the following factors: nature of the business and its assets; goals of conducting the business value assessment, i.e. attracting investment, attracting strategic partner, the sale of intangible assets, sale of business; quantity and quality of data that ground each approach.

Targeted consideration of factors of the innovative development is the decisive criterion for the success of small and medium-sized businesses. Taking into account all factors, it is possible during the formation of financial and legal mechanism of innovative development.

Financial and legal mechanism of innovative development is the system of economic and legal relations that involves the flow of funds on the basis of legal relations between the state and enterprises, which are aimed at achieving a certain level of innovative development through the implementation of quantitative and qualitative transformation of the social system.

The financial and legal mechanism of the innovative development of small and medium-sized enterprises includes a set of goals, ideas, tasks, tools, principles and factors of innovative development (Figure 1, see in Appendix).

At the first stage, the goals of innovative development are determined. Goals may have market, production, organizational, economic, social and environmental nature.

However, this goal-oriented division is conditional, because each goal has organizational components, and some have production and organizational at the same time, etc. Thus, the following goals of innovative development can be determined:

$>$ market (to enter new markets, increase the share of enterprise products in the market); 
$>$ production (to increase the flexibility during the production of goods or services, to increase the capacities for the production of goods or the security services);

$>$ economic (to reduce labor costs, materials and energy consumption per unit of production);

$>$ organizational (to improve the quality of goods or services and reduce the time necessary for innovations to enter the market, improve the quality of production processes);

$>$ social (to improve health quality and level of public safety and improve the life quality of population);

$>$ environmental (to reduce the impact on the environment and reduce the emissions, etc.) [9].

At the second stage of the determination of the level of innovative development, the search and identification of innovative ideas by identifying the market opportunities, technological developments and demand trends are carried out as well the identification of market weaknesses. Therefore, small and medium-sized enterprises need the programs for the identification and information processing about the environment and economic situation. Also, the competitive factors are determined on the basis of which the enterprises operate.

At the third stage the main tasks of innovative development are determined, they can be as follows:

1. Development and implementation of new technologies, innovative products and services (the determining of main directions of innovative improvement and the first implementation of new technologies, products and services on the development of which the efforts are focused; planning and implementation of research and development work, design, start of production and launching of new technologies and devices.

2. Providing high technological level while creating new innovative products (technical re-equipment of production; increase of energy efficiency, labor productivity and product quality in the process of innovations implementation; advanced training of personnel during innovative projects implementation).

3. Formation of corporate mechanisms and structures that facilitate the creation and implementation of innovations (formulation of documents that describe and regulate the main directions of technological development of small and medium-sized enterprises; improvement of system of information support of innovative activity; the formation of administrative structures responsible for technological and innovative development of the enterprise; the implementation of measures aimed at the expansion of scientific and production cooperation, including the examination of the received proposals; improvement of intellectual property management system).

4. Effective cooperation with leading higher education institutions of the country (the determination of subject directions and volumes of joint research (design, technological) works; forming together with hei the research programs in the field of forecasting of scientific and technological development; the implementation of programs (agreed with leading hei) on the improvement of the quality of education and personnel training for the work at the enterprises of small and medium-sized businesses; the participation of these enterprises in the improving of educational program and curricula of hei; participation of employees of enterprises in teaching process).

5. The use of potential of scientific organizations and development institutions (determining the priority directions of cooperation of small and medium-sized businesses with international scientific organizations, national research centers and regional centers of science and high technologies; formation of joint plans of scientific and technological activities and conducting of research to create competitive technologies and products which are the priority ones in the world market).

6. Commercialization of innovative activity results (providing the effective interaction with large innovative enterprises; effective access to new markets, including the international ones) [1].

The tools of financial and legal mechanism of innovative development include the means of regulation of innovative development. The key competencies, programs of scientific and technological development, economic and non-economic incentives are the main ones.

The following principles that govern the formation and success of the implementation of financial and legal mechanism of innovative development are distinguished. There are main principles of continuity, balance, complexity and acceleration.

The principle of continuity provides the maximum reduction (elimination) of time intervals between its stages as well as the constant reproduction of the stages: the search for innovative ideas, their selection, research and development, production of industrial designs, commercialization [2].

The principle of balance consists in that fact that all the activities for the innovative development of small and medium-sized enterprises should be provided with various kinds of resources that are necessary for its implementation: financial, information, material, human [5]. 
The principle of complexity provides that the development of the individual interconnected tasks of innovative development, that ensure the achievement of subgoal, should be carried out in accordance with the general (common) goal of innovative development of small and medium-sized enterprises [6].

The principle of acceleration means fast progression of innovative changes as a result of their implementation into the activities of subjects of small and medium-sized businesses.

The mechanism of innovative development operates effectively if there is a relevant support, i.e., funds that facilitate the normal provision of economic processes. Legal, intellectual, informational, organizational and financial resources are defined as the principal means of ensuring the innovative development mechanism.

Also, the successful functioning of financial and legal mechanisms of innovative development of enterprises as small and medium-sized businesses requires the developed innovative infrastructure that embraces the internal and external fields of such enterprises. The internal field includes material and technical equipment, professional personnel, financial resources and intellectual property. The external field is represented by production and technological, financial, information, education and expert and consulting organizations (Figure 2, see in Appendix).

Thus, financial and legal mechanism is an integrated system of interconnected objects, tools, forms and resources which provide the innovative development of small and medium-sized businesses.

Below, there is the methodology of assessment of innovative development level of small and medium-sized enterprises. The factors of legal field is a distinctive feature of this methodology.

The practical application of the methodology is carried out stage-by-stage. At the first stage, the factors that affect the level of innovative development of small and medium-sized enterprises and system of indicators for each group of factors are determined.

To assess the level of innovative development of small and medium-sized enterprises the following groups of factors are determined:

$>$ Innovative resources (human potential, technologies, research system, financial resources).

$>$ Innovative potential (level of innovative intensity, the level of financial support of innovative activity).

$>$ Innovative activity (expenses for research, number of applications for patents, number of implemented innovations).

$>$ Forms of cooperation with the government (contractual, organizational and legal, special legal regime).

$>$ Legal and regulatory field (laws, regulations, acts, decrees, orders).

Innovative activity is a characteristic of small and medium-sized enterprises and assessed by speed and volume of creation, promotion and use of innovations in business. Innovative resources are the necessary set of components, which the enterprise should have for effective development and implementation of new technologies.

At the second stage, there is the transition from qualitative indicators to the quantitative ones by method of experts evaluation, i.e., the group of experts is determined and every expert assesses the indicators of innovative development of particular enterprise. On the basis of questionnaires with experts' evaluations, the quantitative assessments of each factor of innovative development are calculated and given on a scale from 0 to 5 .

At the third stage, five-component integral component of innovative development of small and medium-sized businesses on the basis of quantitative assessments of separate factors is calculated, according to the formula:

$S(F)=\left\{\begin{array}{l}1, \text { if } f i \geq 3 \\ 0, \text { if } f i<3\end{array}\right.$

where $f_{i}$ - quantitative assessment of each factor of innovative development of small and medium-sized enterprises.

If value of $i$ factor is $f_{i} \geq 3$, its influence on the level of innovative development of small and medium-sized businesses is assessed positively and if $f_{i}<3$, negatively.

Six levels of innovative development of small and medium-sized enterprises are determined depending on particular combination of values of all factors of five-component indicator:

1) if $S=S_{1}\left(f_{i}=1 \forall i\right), f_{i}=0,1 \forall i, i \in(1 \ldots 5)$, then the level of development of small and medium-sized enterprises is high;

2) if $S=S_{2}\left(\sum_{i=1}^{5} f_{i}=4\right), f_{i}=0,1 \forall i, i \epsilon(1 \ldots 5)$ - moderate; 
3) if $S=S_{3}\left(\sum_{i=1}^{5} f_{i}=3\right), f_{i}=0,1 \forall i, i \in(1 \ldots 5)$ - average;

4) if $S=S_{4}\left(\sum_{i=1}^{5} f_{i}=2\right), f_{i}=0,1 \forall i, i \epsilon(1 \ldots 5)-$ low;

5) if $S=S_{5}\left(\sum_{i=1}^{5} f_{i}=1\right), f_{i}=0,1 \forall i, i \in(1 \ldots 5)$ - extremely low;

6) if $S=S_{6}\left(f_{i}=0 \forall i\right), f_{i}=0,1 \forall i, i \in(1 \ldots 5)$-innovative development is impossible.

The calculation of this five-component integral indicator allows to determine the factors that directly constrain and reduce the level of innovative development of small and medium-sized enterprises.

\section{Conclusions}

The article presents the theoretical grounding of necessity for innovative development of small and mediumsized enterprises. The main factors constraining the development of innovative activity of SMEs are determined. It is found out that for the innovative development of SMEs it is necessary to establish correspondence between the potential of innovation and potential of enterprise. For this purpose the following is carried out: the assessment of innovative potential of the enterprise; evaluation of innovative potential of innovation; comparison of two kinds of potentials and development of recommendations for the rational scenario of innovation implementation. Also, the financial and legal mechanism of innovative development of SMEs, which defines the main goals, ideas, tasks, tools and principles of innovative development is developed. Five factors of innovative development of SMEs, depending on which it is possible to define 6 levels of innovative development of these enterprises, are determined.

\section{References}

1. Acs, Z.J., Audretsch, D.B. (1988). Innovation in ladge and small firms: an empirical analysis. American Economic Review, 78(4), 678-690.

2. Chukhraieva, N.M. (2013). Suchasni pryntsypy zabezpechennia innovatsiinoho rozvytku pidpryiemstva. Ekonomika i upravlinnia pidpryiemstvamy [Modern principles of innovative development of the company. Economics and enterprise management]. Ekonomichnyi chasopys-XXI [Economic Annals-XXI], 34(2), 56-63 [in Ukrainian].

3. Kirner, E., Som, O., Dreher, C., Wiesenmaier, V. (2006). Innovation in SMEs - The holistic approach to innovation and the importance of innovation routines for the innovation process. Resource document. Karlsruhe: Fraunhofer ISI. Retirieved from http://publica.fraunhofer.de/starweb/servlet. starweb?path=pub. web \&search=N48930\&format =toc.

4. Kuchynskyi, V.A., Kramskoi, O.U., Andrushenko, A.O. (2009). Rozvytok innovatsiinoho potentsialu pidpryiemstva $\mathrm{v}$ suchasnykh umovakh [The development of innovative potential of enterprise in modern conditions]. Visnyk Natsionalnoho Tekhnichnoho Universytetu "KhPY"[Bulletin of NTU "KhPI"],6, 7074 [in Ukrainian].

5. Maass, F., Leader, B. (2012). Innovation activity in SMEs: measurement and assessment. Resource document. Institut für Mittelstandsforschung (IfM) Bonn. Retrieved from https://www.econstor.eu/bitstream/10419/55666/1/687056292.pdf.

6. Pymenov, S., Vorontsova, M. (2003). Metody izmereniia innovatsyonnoho potentsyala malykh i srednikh predpriiatii [Methods for measuring the innovation potential of small and medium-sized enterprises]. Resource document. ECORYS. Retrieved from http://businessfor.ru/managment/metody izmerenija innovacionnogo potenciala malykh i srednikh predprijatij m $2005 \quad 79$ s.html.

7. Selivanova, N.M. (2016). Novi pidkhody shchodo upravlinnia rozvytkom innovatsiino-aktyvnoho promyslovoho pidpryiemstva na zasadakh kontrolinhu ta yoho kontseptualna model [New approaches to management development of innovative and industrial enterprise on the basis of controlling and its conceptual model]. Ekonomika: Realii Chasu. Naukovyi Zhurnal [Economics: Time Realities. Scientific journal],1(23), 132-141 [in Ukrainian].

8. Shumpeter, I. (1982). Theory of economic development (The study of business profits, capital, credit, interest and conditions cycle). Prohress, $455 \mathrm{p}$.

9. Svechnikova, V.V. (2010). Orhanizatsyonno-ekonomicheskii mekhanizm innovatsyonnoho razvitiia korporativnykh struktur [Organizational and economic mechanism of innovative development of corporate structures]. Cand. Diss. (Economy). Ekaterinburg, 200 p.

10. Welfens, P.J.J., Balcerowicz, L. (1988). Dynamics of innovation in system comparisons: Theory and practice of entrepreneurial, macroeconomic and political innovation. Heidelberg: Physica-Verl. 446 p. 


\section{Appendices}

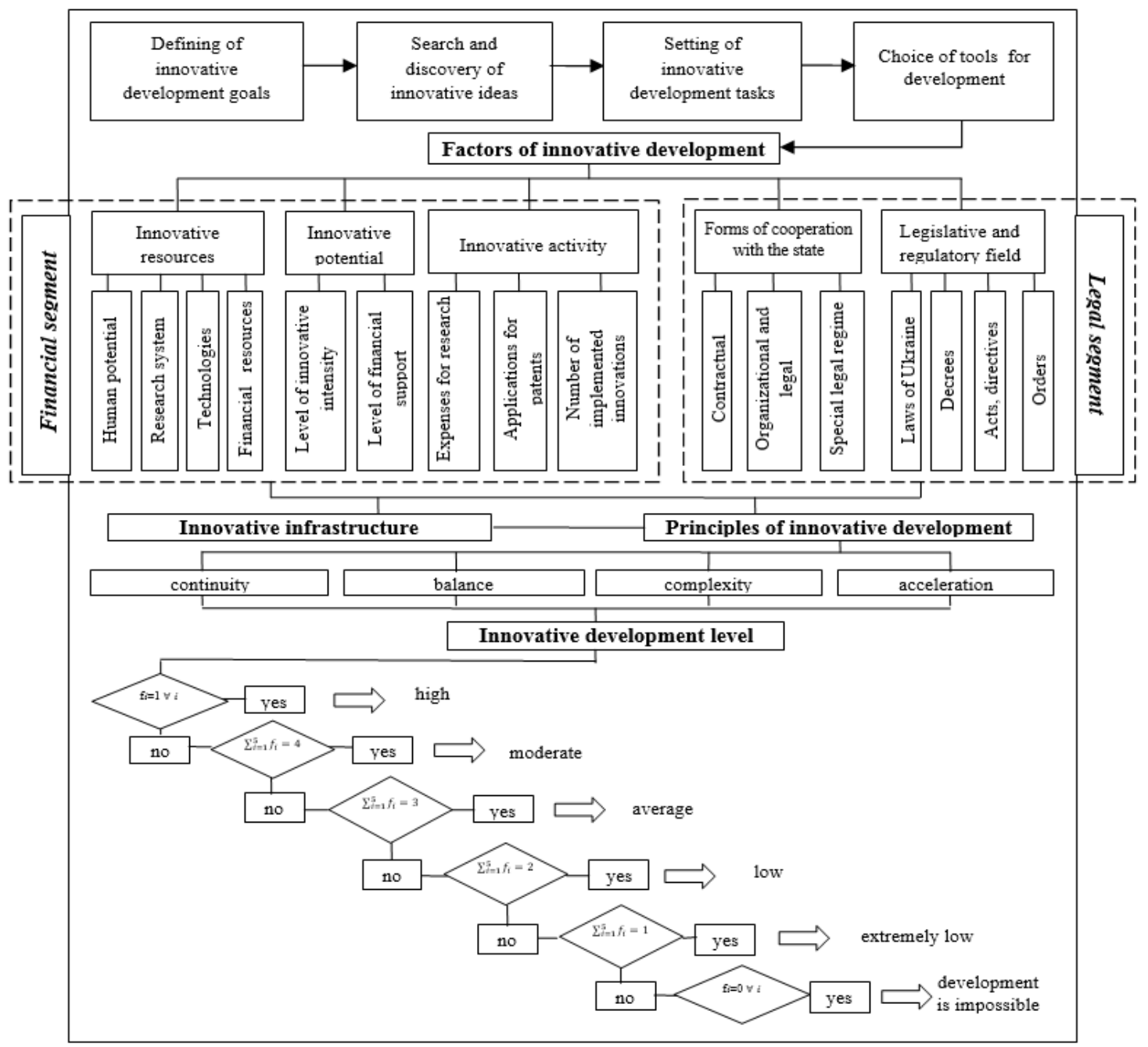

Figure 1. The financial and legal mechanism of the level of innovative development of small and medium-sized enterprises

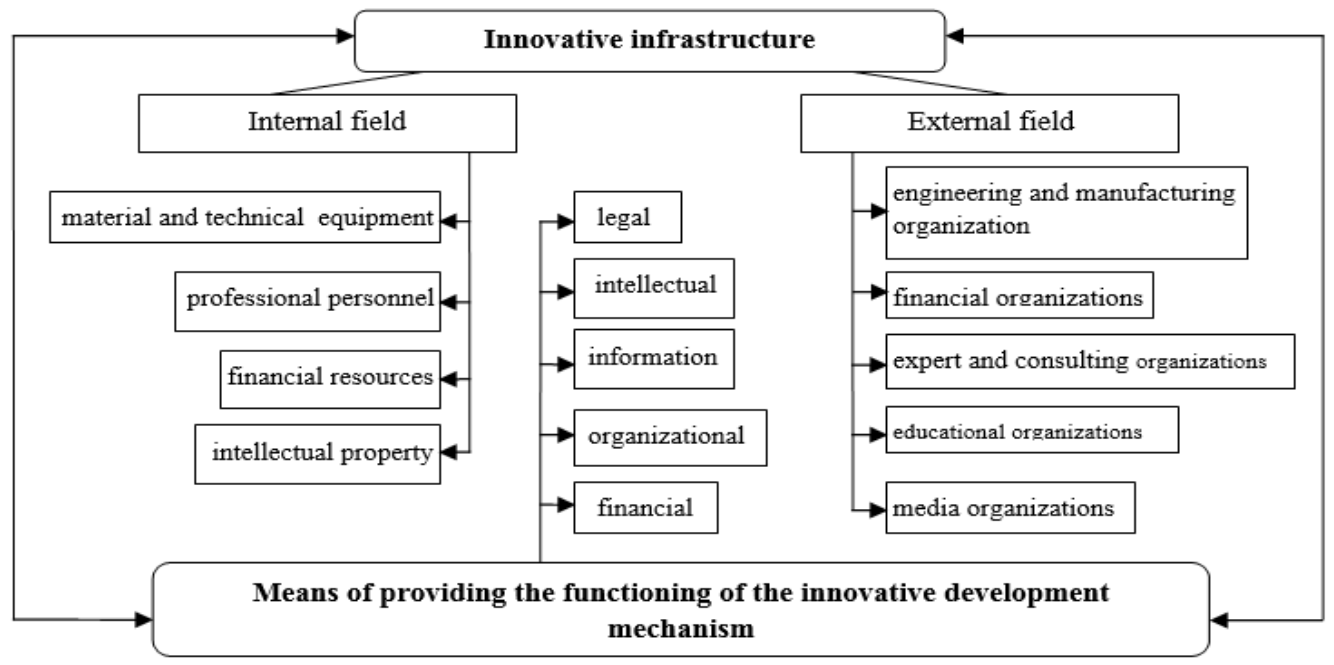

Figure 2. Innovative infrastructure and means of functioning of innovative development mechanism 